\title{
COMMENTS ON "STRATIGRAPHIC DISTRIBUTION OF SHALLOW-WATER BENTHIC FORAMINIFERA FROM THE LOWER CRETACEOUS TAFT FORMATION, CENTRAL IRAN (YAZD BLOCK), WITH EVIDENCE FOR THE IMPORTANCE OF HIATUSES" BY GHEIASVAND, M. ET AL. [ANNALES DE PALÉONTOLOGIE, 2020, 154 (3), 102399] AND RELATED PAPERS
}

\author{
Felix Schlagintweit
}

Received: 8 May 2021 / Accepted: 14 June 2021 / Published online: 16 June 2021

\begin{abstract}
Gheiasvand et al. (2020) use the two larger benthic foraminifera species Simplorbitolina manasi Ciry \& Rat and Mesorbitolina parva (Douglass) (Orbitolinidae) as upper Aptian "potential index fossils" for parts of the Taft Formation in Central Iran. This age assignment is accompanied by changes to well-established orbitolinid biozonations (e.g. occurrence of Praeorbitolina in the late Aptian) with far-reaching implications. These data were also used in a later "multidisciplinary study" (Gheiasvand et al., 2021) for isotopic correlations (e.g., location of OAE`s), delimitation of palaeobiogeographic faunal provinces and related migration patterns. It is shown herein that the taxa identified as S. manasi and M. parva belong to Iraqia simplex Henson and Palorbitolina lenticularis (Blumenbach) respectively documenting a lower and not an upper Aptian age. This revised age and the different taxononomic inventory do not question all results obtained by Gheiasvand et al. $(2020,2021)$, but provide a revised basis interpretation.
\end{abstract}

Keywords: Lower Cretaceous, Orbitolinidae, taxonomy, biostratigraphy, palaeobiogeography

\section{INTRODUCTION}

"Solid taxonomic assumptions are required in cases where the supposed stratigraphic occurrence of certain taxa is used for far-reaching speculations on biogeography and paleoecology. This is because the results may be used later by other workers who are not familiar with micropaleontological issues, for even more far-reaching conclusions, speculations, or hypotheses on more general topics, such as paleogeographic reconstructions in time and space (e.g., plate tectonics)" (Consorti and Schlagintweit, 2020, p. 5). In the last few years, a number of contributions using incorrect taxonomic identifications and resulting age assignments attracted the attention of expert researchers leading to several reply or revisional papers (Granier 2020, 2021; Consorti and Schlagintweit, 2020; Schlagintweit et al., 2020; Simmons 2020, Benedetti 2021). The reasons for this general situation and trend are many-fold. On one side, the publication of incorrect data is facilitated by a growing number of open access journals without a thoughtful peer-review process, or may be due to the limited availability of experts for the review process. On the other side, such contributions may also appear in journals with a high scientific impact and reputation following a poor selection of reviewers by each handling editor. Put simply, papers that contain significant palaeontological content require review by appropriate palaeontological experts (Simmons, 2020). Critical identifications cannot simply be taken on trust. This situation is accentuated because, as Granier (2020) stated, "there is an alarming loss of expertise in systematic and in biostratigraphy" and the future does not expect any improvement of the situation since "academia is not giving much support to this disciplinary field and the number of "specialists" also drastically increases in the industry". In the present contribution, a set of biostratigraphic data from the Lower Cretaceous of Iran (Central Iran and Kopet Dagh Basin) that are basically founded on orbitolinid foraminifera (Gheiasvand et al. 2019, 2020, 2021) are commented upon. If correctly identified, Orbitolinidae can offer a good degree of stratigraphic precision (e.g. Schroeder et al., 2010). The necessity for the present discussion paper is given by the fact that partly incorrect determinations and resulting age constraints have been used for conclusions in sequence stratigraphy (e.g., age of hiatuses), paleobiogeography and palaeoceanographic aspects (based on distribution of certain taxa), and the interpretation of isotopic data obtained from the studied sections (e.g., location of OAE's). The present contribution discusses essentially the biostratigraphic data based on Orbitolinidae and comments on the deduced faunal provinces; all other aspects are not touched upon as they do not lay in the expertise fields of the writer. However, the revised age interpretations clearly call into question some of the wider interpretations.

\section{DISCUSSION}

The results of Gheiasvand et al. $(2020,2021)$ refer to the Lower Cretaceous Taft Formation of Central Iran and Tirgan Formation of the Kopet Dagh Basin, northeastern Iran. 


\section{Biostratigraphy}

\section{Taft Formation of Central Iran}

For two sections of the Taft Formation (Tamer and Tehs sections), Gheiasvand et al. (2020) established an upper Aptian "Mesorbitolina-Simplorbitolina Assemblage Zone" including amongst others, the taxa Praeorbitolina cormyi Schroeder, Praeorbitolina claveli Schlagintweit et al., Simplorbitolina manasi Ciry \& Rat, and Mesorbitolina parva (Douglass). The co-occurrence of Simplorbitolina manasi and Mesorbitolina parva (fig. 8P-R in Gheiasvand et al., 2020; herein reillustrated in Fig. 1a-c), if correctly identified, would indeed indicate an upper Aptian age (Schroeder et al., 2010; Schroeder and Neumann, 1985). Furthermore, the well-established comparably short range of Praeorbitolina in the late early Aptian (upper Bedoulian) recorded from all over the Tethyan realm (e.g. Moullade et al. 1985; Cherchi et al., 1999; Schroeder et al., 2010; Schlagintweit et al., 2013) is questioned by Gheiasvand et al. (2020) who extend its range into the upper Aptian. This assumption was followed as a consequence of the wrong identification of both $M$. parva and $S$. manasi obviously giving their range more credibility. The two sections (axial and transverse) from the Taft Formation are here assigned to Iraqia simplex Henson, a taxon restricted to the late early Aptian to basal upper Aptian (Ullastre et al., 2002; Masse, 2003; Schlagintweit et al., 2016). It has previously been recorded from the lower Aptian Taft (Schlagintweit et al., 2019) and Tirgan formations (e.g., Bucur et al., 2019). The specimen determined as Mesorbitolina parva (Douglass) by Gheiasvand et al. (2019, fig. 8R) is here assigned to Palorbitolina lenticularis (Blumenbach) noting that the structure surrounding the embryo (protoconch and deuteroconch) in slightly oblique transverse section has been interpreted as subembryonic zone (see Schroeder, 1975 for Mesorbitolina) instead of peri-embryonic zone or ring (see Schroeder, 1963 for Palorbitolina). It is important to note that the upper Aptian is well recorded from sections of the Tirgan Formation with Mesorbitolina texana (Roemer) (e.g., Schlagintweit et al., 2019), but cannot be deduced from the data presented by Gheiasvand et al. (2020).

\section{Tirgan Formation of northeastern Iran}

In Gheiasvand et al. (2019a, fig. 5), the Tirgan Formation is attributed to the Berriasian?/lower Valanginian-Aptian interval. The boundary to the overlying Sarcheshmeh Formation consisting of "outer shelf facies" is represented by "an emersion level" placed approximately at the Aptian-Albian boundary. The section log with the "stratigraphic disposition of selected benthic foraminifera" is shown in figure 7 of Gheiasvand et al. (2019a). Unfortunately, neither the shown micro-images of some taxa can be identified and nor less their names. In the middle part of the section, Gheiasvand et al. (2019a, fig. 5) established a "Campanellula capuensis Range Zone" encompassing the early late Hauterivian - early late Barremian interval. The two sections (tangential, fig. $8 \mathrm{~g}$ and subaxial, fig. $8 \mathrm{~h}$ therein) are regarded as "fortunately fairly characteristic of this species", a view that is not shared herein. In fact, the subaxial section shows a biserially coiled small arenaceous, undeterminable foraminifera nicely showing the interio-marginal foramina obliquely alternating between the whorls. Otherwise, the real occurrence of this taxon in the Lower Cretaceous successions of northeastern Iran, part of the former northern Neotethyan margin would be surprising. In fact, the statement of Arnaud-Vanneau and Sliter (1995) is, according to my knowledge, still valid that Campanellula capuensis represents an index species "along the southern margin of the Tethys (Chiocchini and Mancinelli, 1977; Luperto Sinni and Masse, 1986)".

The uppermost part of the Tirgan Formation has been assigned to an "Orbitolinid assemblage Zone" containing Dictyoconus? pachymarginalis Schroeder and Rectodictyoconus giganteus Schroeder, both correctly identified and illustrated (Gheiasvand et al., 2019a, fig. 9a-b and 9ik). Unfortunately, the distribution (e.g. overlapping?) of the two taxa cannot be deciphered in figure 7 therein. The occurrence of orbitolinids is said to "persist up to the top of the Tirgan Fm.” In Gheiasvand et al. (2019b), referring to the same section studied, other orbitolinids of this "upper Aptian assemblage zone" are illustrated as Simplorbitolina sp. (pl. 2, figs. 1-2 therein) and Praeorbitolina? or Palorbitolina transiens (pl. 2, fig. 4 therein) here reillustrated in Figure 1d-f and detail in e. The two supposed sections of Simplorbitolina are here assigned to Iraqia simplex Henson, Rectodictyoconus giganteus Schroeder and Praeorbitolina claveli. It is worth to mention that another specimen (oblique section) of Iraqia simplex has been illustrated (but not mentioned) in a microfacies image in Gheiasavand et al. (2021, fig 5F). Praeorbitolina claveli species has been described from the lower Aptian of the Taft Formation (Schlagintweit et al., 2013), and is recorded for the first time from the Tirgan Formation. For comparison purpose, some specimens from the type-material are illustrated (Fig. 1g-j). As in the investigation of the authors of the Taft Formation of Central Iran, the group of Praeorbitolinas, here including $P$. cormyi Schroeder and $P$. claveli Schlagintweit et al. (= Praeorbitolina? or Palorbitolina transiens? in Gheiasvand et al., 2019b, pl. 2, fig. 4) have also been reported from the "Orbitolinid Assemblage Zone" assigned to the late Aptian. Instead of questioning their own determinations, Gheiasvand et al. (2019a) extended the range of Praeorbitolina into the late Aptian in the same way they did for the Taft Formation (Gheiasvand et al., 2019a, b). In fact, Gheiasvand et al. (2019a, p. 12) argued that they observed "Praeorbitolina cormyi and P. claveli, which are recognized from the Lower Aptian successions... Here they occur together, with microfossils of the late Aptian". Last but not least the top most part of the Tirgan Formation shows an upper Aptian "Planktonic Assemblage 


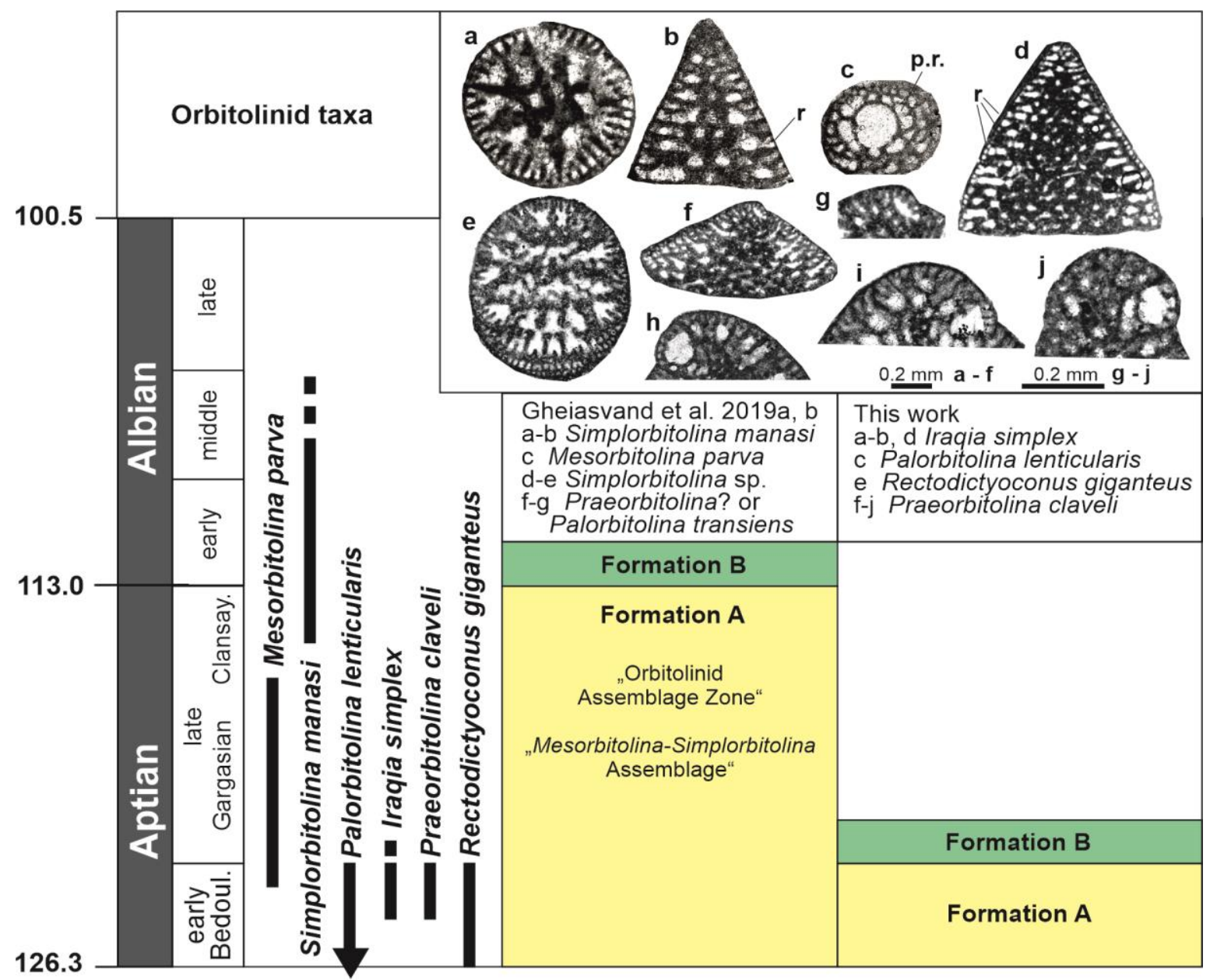

Fig. 1. Orbitolinids from the Aptian of the Taft Formation of Central Iran (a-c, h-j, "Orbitolinid Assemblage Zone") and the Tirgan Formation of northeastern Iran (Kopet Dagh Basin) (d-f, "Mesorbitolina-Simplorbitolina Assemblage" Gheiasvand et al., 2012), their determination according to Gheiasvand et al. (2019a, b) and this work, and the differing associated biostratigraphy. Note the differences in the location of two formation boundaries. h-j Praeorbitolina claveli Schlagintweit et al., type-material from the late early Aptian of the Taft Formation. Ranges adopted from Cherchi and Schroeder (2013), Schroeder et al. (2012); Moullade and Peybernès (1975) and Schroeder and Neumann (1985) for $S$. manasi; Masse (2003) for Iraqia simplex; Schlagintweit et al. (2013) for Praeorbitolina clavelin.

Zone". Whether or not the determination of Colomiella sp. (fig. $8 \mathrm{v}$ therein) is correct is not discussed herein. In this assemblage zone, benthic foraminifera are present that should, according to Gheiasvand et al. (2019, p. 11) also include Reticulinella reicheli, a species known from the late middle Cenomanian (e.g. Yazdi-Moghadam and Schlagintweit, 2021, fig. 2H) to the late Upper Cretaceous (probably upper Maastrichtian; Cuvillier et al., 1969). It is noteworthy that previous works that place the top of the Tirgan Formation beneath the overlying Sarcheshmeh Formation within the late early Aptian based on orbitolinid foraminifera (e.g., Bucur et al., 2019) were not discussed.

\section{Palaeobiogeography}

The data (e.g. benthic foraminifera) obtained by Gheiasvand et al. (2021, p. 11) "outlines new global palaeobiogeographic reconstruction models for the different areas". Based on these data six faunal provinces were defined: "northern and southern Neotethys, northern and southern Alpine Tethys, Gulf of Mexico and northern Pacific Ocean". In addition, faunal migration routes between these realms (or provinces) were either "certainly established" or "assumed". Among several "index taxa" that are in my opinion, highly problematic to be exactly determined in random thin-sections (e.g. species of Bolivinopsis, Arenobulimina, Decussoloculina) also incorrectly identified taxa such as Campanellula capuensis or Simplorbitolina manasi went into these "models". Another orbitolinid used in the distributional pattern maps, Orbitolinopsis nikolovi Peybernès et al., has "never been recorded in the northern Neotethys" (Gheiasvand et al., 2021 , p. 10). In fact, the only oblique section of "Orbitolinopsis cf. nikolovi" illustrated in Gheiasvand et al. (2019b, pl. 2, fig. 6) represents a badly preserved orbitolinid that might be referred to Orbitolinopsis. In my opinion, the three specimens of Orbitolinopsis nikolovi illustrated in the original description by Peybernès et al. (1979, pl. 1, figs. 3-5) are considered juvenile specimens 


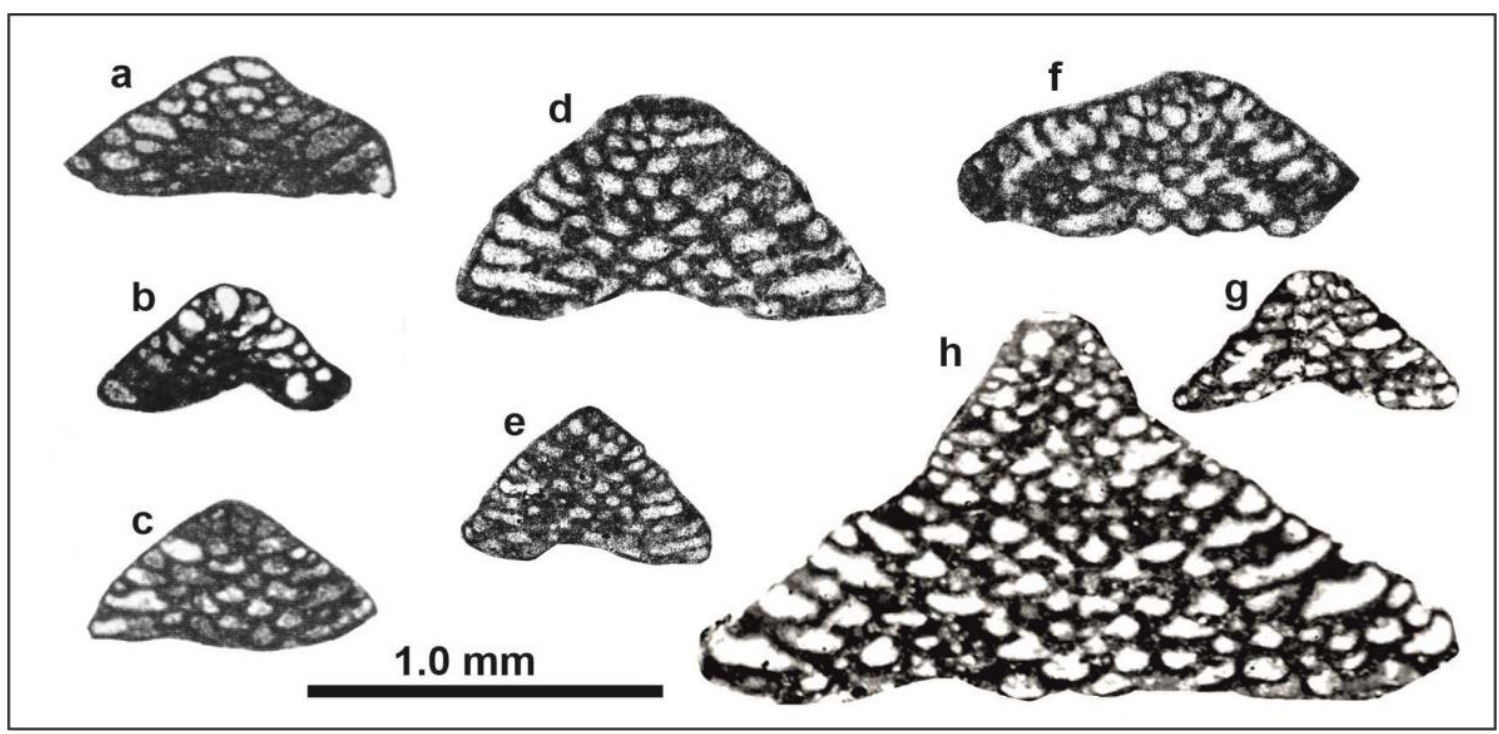

Fig. 2. Orbitolinopsis nikolovi Peybernès et al. (a-c; interpreted as juvenile specimens; $\mathbf{a}=$ holotype, early Aptian of Bulgaria), a subjective junior synonym of Orbitolinopsis buccifer Arnaud-Vanneau \& Thieuloy (e-f, upper Berriasian of eastern Serbia, see Bucur et al., 2020; g-h, unpublished specimens from the Lower Cretaceous of southeastern France; leg. B. Clavel; note adult specimen in $\mathbf{h})$.

of Orbitolinopsis buccifer Arnaud-Vanneau \& Thieuloy, comparable to those reported by Clavel et al. (2014) from the Lower Cretaceous of southeastern France, and thus a junior synonym of the latter (Fig. 2). Orbitolinopsis buccifer has been recorded recently from the Lower Cretaceous of eastern Serbia (Bucur et al., 2020), that belongs to the same palaeogeographic realm (CarpathoBalkanides) as the type-locality of "Orbitolinopsis nikolovi". Southeastern France, and the CarpathoBalkanides (here: Bulgaria, eastern Serbia) formerly belonging to the northern Neotethyan margin. Previous papers dealing with the palaeobiogeographic distribution of Orbitolinidae (Cherchi et al., 1981; Pelissié et al., 1982; Bassoullet et al. 1985; Schlagintweit, 1991) were not referenced and the provinces discussed therein not mentioned. One would at least have expected that the existing data for the Orbitolinid taxa (e.g., "biospace d'Orbitolinopsis capuensis", "province á Simplorbitolina manasi" or "Orbitolinopsis gr. cuvillieri-kiliani-buccifernikolovi province" of Bassoullet et al., 1985) would be mentioned by Gheiasvand et al. (2021).

\section{CONCLUSIONS}

The biostratigraphic data of Gheiasvand et al. (2019a, b, 2020, 2021) shows a lower and not an upper Aptian age for the top of the Tirgan Formation of northeastern Iran and the studied two sections of the Taft Formation in Central Iran. The lower Aptian age for the top parts of the Tirgan Formation is in accordance with all previous investigations. The misinterpretations derive from wrong determinations of Orbitolinidae (e.g., Simplorbitolina manasi instead of Iraqia simplex and Mesorbitolina par$v a$ instead of Palorbitolina lenticularis). The extension of the range of any species of Praeorbitolina into the upper
Aptian should be rejected. So far, no specimen of Mesorbitolina has been reliably been illustrated from the Tirgan Formation. The upper Aptian however is well recorded from the Taft Formation of Central Iran (e.g., occurrence of Mesorbitolina texana) but cannot be deduced from the biostratigraphic data by Gheiasvand et al. (2020). All other conclusions about isotope data curves, delimitation of bioprovinces, and sequence stratigraphic correlations of hiatuses have to be questioned as they are based on a very weak biostratigraphy. The present reply paper represents another example that "emphasises the need for rigorous micropalaeontology....supported by definitive illustrations and reference to key literature" (Simmons, 2020).

\section{ACKNOWLEDGEMENTS}

Many thanks to the late Bernard Clavel who provided images from Orbitolinopsis buccifer with permission to use them. The helpful remarks provided by the reviewers Lorenzo Consorti (Rome), Mohsen Yazdi-Moghadam (Tehran) and Mike Simmons (London) are kindly acknowledged.

\section{REFERENCES}

Arnaud-Vanneau, A. \& Sliter, W.V., 1995. Early Cretaceous shallow-water benthic foraminifers and fecal pellets from Leg 143 compared with coeval faunas from the Pacific Basin, Central America, and the Tethys. Proceedings Ocean Drilling Program, Scientific Results, 143: 537-564.

Bassoullet, J.P., Fourcade, E., Peybernès, B. 1985. Paléobiogéographie des grands Foraminifères benthiques des marges néo-téthysiennes au Jurassique 
et au Crétacé inférieur. Bulletin de la Société géologique de France, t. 1, 5: 699-713.

Benedetti, A., 2021. Comments on "Larger benthic foraminiferal assemblages and their response to Middle Eocene Climate Optimum in the Kohat Basin (Pakistan, eastern Tethys)" by Kamran et al. Palaeoworld, https://doi.org/10.1016/j.palwor.2020.09.004.

Bucur, I.I., Yarahmadzahi, H. \& Mircescu, C.V., 2019. The Lower Cretaceous Tirgan Formation in the Gelian section (Kopet Dagh, North Iran): Microfacies, microfossils, and their biostratigraphic significance. Acta Palaeontologica Romaniae, 15 (1): 13-33.

Bucur I.I., Sudar M., Schlagintweit F., Pleş G., Săsăran E., Jovanović D., Polavder S. \& Radoičić, R., 2020. Lowermost Cretaceous limestones from the Kučaj zone (Carpatho-Balkanides, Eastern Serbia): new data on their age assignment. Cretaceous Research, 116: article 104575.

Cherchi, A., Durand-Delga, M. \& Schroeder, R. 1981. Apercu paléogéographique sur les Provinces à grands Foramninifères du Crétacé Inférieur dans le Cadre structural Méditerranéen. Rapport Commission internationale pour l'exploration Mer Méditerranée, 27, 115-119

Cherchi, A., Schroeder, R. \& Bin Ghoth, M., 1999. Early Aptian orbitolinid foraminifera from the Qishn Formation of Al Mukalla (Hadramawt, Southern Yemen). Comparisons with adjacent regions. Zeitschrift für geologische Wissenschaften, 26 (5-6): 543-561.

Cherchi, A. \& Schroeder, R., 2013. The PraeorbitolinalPalorbitolinoides association: an Aptian biostratigraphic key-interval at the southern margin of the Neo-Tethys. Cretaceous Research, 39: 70-77.

Chiocchini, M., \& Mancinelli, A., 1977. Microbiostratigrafia del Mesozoico in facies di piattaforma carbonatica dei Monti Aurunci (Lazio meridionale). Studi Geologici Camerti, 3: 109-152.

Consorti, L. \& Schlagintweit, F., 2020. Comment on "Does specialization imply rare fossil records of some benthic foraminifera: Late Palaeocene examples from the eastern Neo-Tethys (Meghalaya, NE India)" by Suman Sarkar [Palaeogeography, Palaeoclimatology, Palaeoecology, 514 (2019) 124-134. Palaeogeogr., Palaeoclimatol., Palaeoecol., 539: 109525.

Cuvillier, J., Bonnefous, J., Hamaoui, M. \& Tixier, M., 1969. Reticulinella reicheli, nouveau foraminifère du Crétacé Supérieur. Bulletin du Centre de Recherches de Pau-SNPA, 3 (2): 207-257.

Henson, F.R.S., 1948. Larger imperforate Foraminifera of south-western Asia. Families Lituolidae, Orbitolinidae and Meandropsinidae. Monograph British Museum (Natural History), 127 p.

Gheiasvand, M., Föllmi, K.B., Arnaud-Vanneau, A., Adatte, Th., Spangenberg, J., Ghaderi, A. \& Ashouri, A.R., 2019a. New stratigraphic data for the Lower Cretaceous Tirgan Formation, Kopet Dagh Basin, NE Iran. Arabian Journal of Geosciences, 12: 142.
Gheiasvand, M., Ashouri, A.R., Aghanabati, S.A., Taherpour Khalil Abad, M. \& Ghaderi, A., 2019b. Biostratigraphy of the Tirgan Formation in the KopetDagh Basin: Stratigraphic sections of the Tirgan village and Amirabad. Journal of Stratigraphy and Sedimentology Researches University of Isfahan, 35 (issue 1, no.74), 23-36.

Gheiasvand, M., Ashouri, A.R., Aghanabati, S.A., Taherpour-Khalil-Abad, M. \& Ghaderi, A., 2020. Stratigraphic distribution of shallow-water benthic foraminifera from the Lower Cretaceous Taft formation, Central Iran (Yazd Block), with evidence for the importance of hiatuses. Annales de Paléontologie, 106 (3): 102399.

Gheiasvand, M., Föllmi, K.B., Stampfli, G.M., Vérard, C., Luciani, V. \& Morsilli, M., 2021. Paleoenvironment and paleobiogeography of Lower Cretaceous carbonate successions of the northern Tethyan margin: Examples from Northeastern and Central Iran. Journal of Asian Earth Sciences, 213: 104752.

Granier, B., 2020. Discussion of the paper by Vincent et al., 2018, entitled "Age constraints on intraformational unconformities in Upper Jurassic-lower Cretaceous carboinates in northeast Turkey: geodynamic and hydrocarbon implications" (Marine and Petroleum Geology, 91, 639-657). Marine and Petroleum Geology, 112: 103795.

Granier, B., 2020. Discussion of the paper by Imad M. Ghafor and Ibrahim M.J. Mohialdeen, 2018, entitled "Early Cretaceous microfossils associations (foraminifera, ostracoda, calcareous algae, and coral) from the Garagu formation, Dukok area, Kurdistan region, northern Iraq" (Arabian Journal of Geosciences, 11: 407). Arabian Journal of Geosciences, 13: 60.

Hottinger, L. \& Drobne, K., 1980. Early Tertiary conical imperforate foraminifera. Razprave IV. razr. SAZU, 22: 188-276.

Kaminski, M.A., 2014. The year 2010 classification of the agglutinated foraminifera. Micropaleontology, 60(1): 89-108.

Loeblich, A.R., Jr. \& Tappan, H., 1987. Foraminiferal genera and their classification, Van Nostrand Reinhold, New York, 2 vol., 970 p., 847 pls.

Luperto Sinni, E., and Masse, J.P., 1986. Données nouvelles sur la stratigraphic des Calcaires de plateforme du Crétacé inférieur du Gargano (Italie meridionale). Rivista Italiana di Paleontologia e Stratigrafia, 92: 33-66.

Masse, J.P., 2003. Integrated stratigraphy of the Lower Aptian and applications to carbonate platforms: a state of the art. In: Gili, E., Negra, M.E.H. \& Skelton. P.W. (eds.). North African Cretaceous Carbonate Platform Systems, Nato Science Series, 203-214.

Moullade, M. \& Peybernès, B., 1975. Biozonation par Orbitolinidés du Clansayesien et de l'Albien calcaires des Pyrénées franco-espagnoles. Comptes Rendus de 1'Académie des Sciences, Sér. D, 280: 2529-2532. 
Moullade, M., Peybernès, B., Rey, J. \& Saint-Marc, P., 1985. Biostratigraphic interest and paleobiogeographic distribution of early and mid-Cretaceous Mesogean orbitolinids (Foraminiferida). Journal of Foraminiferal Research, 15 (3): 149-158.

Pelissié, T., Peybernès, B. \& Rey, J., 1982. Tectonique des plaques et paléobiogéographie des grands Foraminifères benthiques et des Algues calcaires du Dogger à l'Albien sur le pourtour de la Mésogée. Bulletin de la Société géologique de France, (7), 24 (5-6): 1069-1076.

Peybernès, B., Conrad, M.A. \& Cugny, P., 1979. Contribution á l'étude biostratigraphique, micropaléontologique et paléoécologique des calcaires Urgoniens du Barrémo-Bédoulien Bulgare (Prébalkan et plate-forme Moésienne). Revue de Micropaléontologie, 21 (4): 181-191.

Schlagintweit, F., 1991. Neritische Oberjura- und Unterkreide-Kalkgerölle aus den Losensteiner Schichten (Alb-Cenoman) der Typlokalität Stiedelsbachgraben (Oberösterreich; Nördliche Kalkalpen). Mitteilungen der Gesellschaft der Geologie- und Bergbaustudenten Östrerreich, 37: 8395.

Schlagintweit, F., Bucur, I.I., Rashidi, K. \& Saberzadeh, B., 2013. Praeorbitolina claveli n. sp. (benthic Foraminifera) from the Lower Aptian sensu lato (Bedoulian) of Central Iran. Carnets de Géologie (Notebooks on Geology), Letter 2013/04 (CG2013_L04).

Schlagintweit, F., Ghanbarloo, H., Safari, A. \& VaziriMoghaddam, H., 2020. Loftusia persica Brady, a Maastrichtian larger benthic foraminifera and not an Eocene Lazarus taxon. Micropaleontology, 66 (5): 419-423.
Schlagintweit, F., Rashidi, K. \& Hanifzadeh, R., 2019. Campanellula herishtensis $\mathrm{n}$. sp. (Foraminiferida; Orbitolinidae?) from the upper Aptian (Gargasian) of Central Iran. Neues Jahrbuch Geologie und Paläontologie Abhandlungen, 294 (3): 251-161.

Schlagintweit, F., Rosales, I. \& Najarro, M., 2016. Glomospirella cantabrica n. sp., and other benthic foraminifera from Lower Cretaceous Urgonian-type carbonates of Cantabria, Spain. Geologica Acta, 14 (2), 113-138.

Schroeder, R., 1963. Palorbitolina, ein neues Subgenus der Gattung Orbitolina (Foram.). Neues Jahrbuch für Geologie und Paläontologie Abhandlungen, 117: 346-359.

Schroeder R., 1975. General evolutionary trends in orbitolinas. Revista Española de Micropaleontologia, Num. esp. 1975: 117-128.

Schroeder, R. \& Neumann, M. (coords.), 1985. Les Grands Foraminifères du Crétacé Moyen de la région Méditerranénne. Géobios, Mémoire Special, 7: 1-161.

Schroeder, R., Van Buchem, F.S.P., Cherchi, A., Baghbani, D., Vincent, B., Immenhauser, A. \& Granier, B., 2010. Revised orbitolinid biostratigraphic zonation for the Barremian-Aptian of the eastern Arabian Plate and implications for regional stratigraphic correlations. GeoArabia, Special Publication, 4: 4996.

Simmons M. 2020. Comments on "Facies modeling of synchronous successions - A case study from the mid-cretaceous of NW Zagros, Iran" by Shoghi et al., J. Afr. Earth Sci., 162 (2020) 103696. Journal of African Earth Sciences, 170: 103902.

Ullastre, J., Schroeder, R. \& Masriera, A., 2002. Sobre la estratigrafía del singular corte de la Roca de Narieda (parte S de la serie del Cretácico inferior de Organyá). Pirineo catalán. España. Treballs del Museu de Geologia de Barcelona, 11, 67-95. 